\title{
Radio Rules in the Making
}

Congress Considering the Recommendations of the Radio Conference and in Modified Form Will Mold Them Into a New Law

\author{
By George H. Dacy
}

R ADIO fans, the country over, who for many weeks R have been scanning the newspapers looking for information about the new laws of the ether and radio art, may think that the national radio experts of our Federal legislators are taking their own sweet time in the consileration and passage of the new radio rules. The old saw about "Rome not being built in a day," pretty well applies to the consideration and formulation of the twentieth century radio legislation. The members of the radio conference, the most famous meeting of its kind in the history of radio, have made haste slowly in their surveys and studies of the needs of industry. They have carefully considered and weighed in the balance each detail and each issue. The best brains and knowledge of the radio art have been occupied for several months now in investigating the fundamental needs of legal changes in the Federal laws which pertain to wireless telephony and telegraphy. Now all this minute consideration and detailed discussion by the experts will result in the consummation of a radio law which will be letterperfect and still flexible enough to dovetail with the rapid potential development of the industry.

As has been previously noted at length in the May and June issues of Screntrific American the American Radio Conference initially met at Washington under the chairmanship of Secretary of Commerce Herbert Hoover during the period from February 27 to March 2. At the end of this session, a tentative report was prepared and sent to all persons who requested it and to the representatives of the various interests which in the judgment of the Department of Commerce were interested. Subsequently, a large number of comments and suggestions were received from all parts of the country. On April 17, 18, and 19, the Radio Conference as a whole held additional meetings, the special technical committee having held daily meetings in the interim

At these April sessions of the Conference all the comments and suggestions were considered, the general effect of these approbations or criticisms being to approve with a few trifling exceptions the substance of the preliminary report. Thereupon, the report was finally amended and adopted. In addition to preparing a report on technical matters, the Conference made recommendations as to essential points required in legislation to give the Secretary of Commerce authority

necessary to accomplish the ends recommended through the power to make and enforce regulations. In the main, these recommendations were presented in the June issue of Scientrfic American. Additional agreements were reached which provided that the operation of the Government radio stations be conducted in such a manner as not to interfere with the commercial traffic and broadcasting, and that whenever Governmentowned stations are used for the transmission of commercial traffic and broadcasting, they shall conform to the regulations established by the Secretary of Commerce. It was also agreed to add a provision for the appointment by the President of an Advisory Committee to the Secretary of Commerce, to consist of not more that twelve members, half of whom shall be selected from the Government service and agencies and the other half from commercial circles outside the Government service.

At the time when this article was written, the recommendations of the Radio Conference had not been prepared into bill form and introduced into the House of Representatives as pending legislation. It so happens that Representative Wallace $\mathrm{H}$. White, Jr., of Maine, one of the prominent members of the Radio Conference and selected by that body to draft the recommendations into bill form and introduce them into Congress, has been so busy with committee meetings and hearings on the Merchant Marine legislation appropriation that he has been unable as yet to draw up the radio rules and launch the proposed legislation into Congress for discussion and ratification or rejection. Recently, the writer talked at length with Mr. White about the makeup of the new bill which will be in the hands of Congress at the latest by the third week in May. The information and data which follow come directly from Congressman White, who will act as father and

chaperon to our new radio rules during their sojurn in Congressional circles.

The proposed radio legislation is emergent in character. The bill as it will be introduced will not be a comprehensive radio law. It will alter the former radio act passed in 1912 only in those respects where it is now obsolete as a result of the expansion and development of the radio industry. Only the essentially vital points which must necessarily be altered will be changed. At this time, it is not considered advisable by the radio experts to cover the entire field of the industry as this would involve too great delay. The factor that is most urgent is the satisfactory and permanent elimination as far as possible of interference in the ether, and it is thought that this can be accomplished so far as legal requirements are concerned by a comparatively simple bill.

The substantial and outstanding features of the proposed bill will consist of a re-drafting of sections 1, and 3 of the present law which was ratified a decade ago. It is anticipated that these alterations will clarify and reinforce the existing law by enlarging the essential regulatory powers to the extent deemed necessary. In its present tentative forms, the bill provides that radio apparatus shall not be used as a means of inter course between the several States or with foreign nations or for the transmission of signals, the effects of which extend beyond the State in which the signals are made, except under a special license granted by the Secretary of Commerce. This applies, it will be

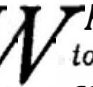
HAT has happened to the new and revised radio laws that were a follow the Radio Conference and the numerous discussions in and out of radio regarding the present and future regulation of broadcasting art? Has the matter been dropped? Or has the revi-

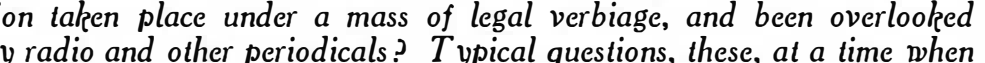
eryone is interested in knowing what is to become of radio-phone roadcasting in the first place, and radio communication in general. Rest assured, however, that we have not lost sight of radio legislative easures. We have commissioned Mr. George H. Dacy of Washington, . C., to follow the developments most carefully, and this he has dione continues to do. His present report is the third of a series that will satisfactorily interpreted for our full understanding.-THE EDITOR.

granting very general regulatory powers to the Secreas flexible as the art itself. Changes can be made as frequently as the vital occasion for such alterations arises. The opinion prevails that such authority will fortify and equip the Secretary of Commerce so that first national Radio Conference.

The proposed radio law will make certain and definite what is now doubtful-that it is not mandatory upon the Secretary of Commerce to issue a license to any applicant, but that this granting of licenses will rest (his sound discretion. Under the existing law, bill will definitely fix the limit of time that a license will last and also will make certain that the Secretary of Commerce is authorized with complete powers of revocation of license. The revised rules will emphasize the fact that although a certain wave length may be whe granted only to Americans and that their rights sent of the Secretary of Commerce.

The status of the amateur fixed very definitely by the radio act of 1912 will be respected religiously. Iis rights will be somewhat enlarged in the way of wave lengths to which he will be entitled. An assignment of wave lengths to amateurs up to 275 meters probably will be made. Under the present law, the amateur has wave lengths up to 200 meters. Under the revised rules, the amateurs, however, will not have exclusive use of the ether between 200 and 275 meters. A schedule of fees for licenses also probably will be included in the radio bill which is in the making. The service now costs the Government in the neighborhood of $\$ 250,000$ a year and there is no reason why those for whom the regulations are made and the service maintained should not contribute in a small way to the support of the service. The fees will range from a nominal charge of 50 cents per annum to a maximum of $\$ 50$. The larger tax will be assessed against the large trans-oceanic stations. 'The amateurs, for the most part, will have to pay only the minimum fee.

observed, only to transmitting stations and in no wise effects receiving stations.

By authority of the proposed legislation, the Secre tary of Commerce is empowered to classify radio stations and the operators thereof; to prescribe the nature of the class of service to be rendered by each type of station; to assign bands of wave lengths; to make regulations concerning the class of service to be rendered by each class of station; to be the court of last appeal regarding the location of each station; to dictate the wave lengths and the kind of instruments to be used with regard to the external effect produced by themthe power, parity and sharpness of the waves, the times and methods of operating the stations. Briefly, the Secretary of Commerce is given blanket authority to establish such emergency regulations as-from time to time-are needed and, at all times, to act as hensiders advisable for the protection and best interest of the industry.

The opinions of Representative White and the radio experts were that right now the industry is in a stat of flux. They think it would be unwise under such conditions to write into the law hard and fast rules and other detailed provisions which are liable to require revision only a few days or weeks after enactment as measured by the present rapid development of the radio art. It is a hard enough matter to guid egislation successfully through Congress, but it is still slower and more laborious task to alter and amend the laws once they are passed. If very stringent and precise regulations were established at this time, it might be that 24 hours after the new rules were ratified some untoward condition might develop which would ender them a handicap rather than a help. The consensus of opinion of the Radio Conference was that such conditions could only be met satisfactorily by
Report of the Fourteenth Annual Conference on Weights and Measures

HERE was held last May at the National Bureau of Standards the Fourteenth Annual Conference on Weights and Measures, attended by officials from all sections of the country. These conferences have become one of the most important of the numerous meetings that take place each year at the bureau, and as a result of the papers presented and the discussions which take place, greater uniformity is being secured in the important matter of the weights and measures now in. use in our various states and cities, and the regulations force governing these.

It should be remembered that the National Government does not regulate these matters in this country. The enforcement of proper laws governing the use of weighing and measuring appliances is left entirely to the states and cities, a procedure which undoubtedly has some advantages and also some disadvantages, among which is the lack of uniformity in regulations in different parts of the United States. The weights and measures conferences, however, have done a great deal toward unifying and simplifying the various laws. At the last conference important work was done in framing a model law for the sale of bread by weight and in further improving the specifications for liquid measuring appliances.

A circular describing fully the results of the conference has recently been issued, known as Miscellaneous Publication No. 48 of the Bureau of Standards. It may be obtained from the Superintendent of Documents, Government Printing Office, Washington, D. C., at 20c per copy. The circular should prove of greatest interest to all those engaged in the construction, use or inspection of weighing and measuring appliances. 